\title{
Ecological preferences of large carnivores in remote, high-altitude protected areas: insights from Buxa Tiger Reserve, India
}

\author{
Mriganka Shekhar Sarkar, Harika Segu, J. V. Bhaskar, Rajendra Jakher \\ Shati Mohapatra, K. Shalini, S. Shivaji and P. Anuradha Rediy
}

\begin{abstract}
Difficult terrain and inclement weather limit our knowledge of large predators, such as the tiger Panthera tigris, in the Himalayas. A lack of empirical data on large carnivores can lead to mismanagement of protected areas and population declines. We used non-invasive genetic and remote sensing data to inform the management of such high-altitude protected areas. We used the tiger as a focal species to investigate prey preference and habitat suitability in India's Buxa Tiger Reserve, which encompasses several eco-geographical regions in the Himalayan and subtropical zones. During 2010-2013, 909 faecal samples were collected, of which 372 were confirmed, using genetic analysis, to be of tiger origin. Fourteen prey species/groups were identified in 240 tiger faecal samples, largely dominated by goats Capra spp. (26.59\%), rhesus macaques Macaca mulatta (22.22\%) and cattle Bos spp. (20.63\%). Considering only the wild prey species for which survey data are available, however, and frequency of occurrence of prey in faecal samples, hog deer Axis porcinus, sambar deer Rusa unicolor and spotted deer Axis axis were the most preferred prey species. Using faecal sample locations to examine the relationship between tiger presence and environmental features indicated that the niche for tigers is narrower than the available protected area: c. $62 \%$ of core protected area is suitable, of which only $17 \%$ is highly suitable for tigers. Tigers prefer dense vegetation, open forests, riverine vegetation and areas close to water sources. Faecal sample-based studies have the potential to generate data that can help us understand the ecology of elusive carnivore species inhabiting high-altitude landscapes.
\end{abstract}

Keywords Buxa Tiger Reserve, ecological niche factor analysis, faecal samples, India, Mahalanobis distance, Panthera tigris, prey preference, tiger

Supplementary material for this article can be found at https://doi.org/10.1017/So030605317000060

Mriganka Shekhar Sarkar ${ }^{*}$, Harika Segu, Swati Mohapatra, K. Shalini, S. Shivaji and P. Anuradha Reddy (Corresponding author) Council of Scientific and Industrial Research - Centre for Cellular and Molecular Biology, Uppal Road, Hyderabad 500 007, India E-mail anuradha@ccmb.res.in

J. V. Bhaskar and Rajendra Jakher Forest Department, West Bengal, India

*Also at: Wildlife Institute of India, Dehradun, India

Received 29 September 2016. Revision requested 2 November 2016.

Accepted 11 January 2017. First published online 31 July 2017.

\section{Introduction}

Trar here is increasing recognition of the important roles played by apex predators in maintaining ecosystems and sustaining biodiversity. Predators regulate the abundance of herbivore populations (Sih et al., 1985; Schoener, 1993; Menge, 1995, 1997), their diversity in an ecosystem potentially affects prey density (Lima, 1998; Sih et al., 1998), they control meso-predator populations (Ritchie \& Johnson, 2009), and they play a distinct functional role in the cascading effect at each trophic level (Polis \& Hurd, 1996; Polis \& Strong, 1996; Polis, 1999).

Himalayan and subtropical ecosystems are unique in being dominated by only a few species of predators. The snow leopard Panthera uncia, clouded leopard Neofelis nebulosa, Himalayan brown bear Ursus arctos isabellinus, Asiatic black bear Ursus thibetanus and Himalayan wolf Canis lupus himalayensis occur in the Himalayan and trans-Himalayan rangeland (Dinerstein \& Mehta, 1989; Fox et al., 1991; Mishra, 1997; Sathyakumar, 2001; Mishra et al., 2006, Sathyakumar et al., 2011), whereas the tiger Panthera tigris and leopard Panthera pardus occur in the subtropical Terai landscape (Smith et al., 1999). The snow leopard and tiger are categorized as Endangered on the IUCN Red List (Jackson et al., 2008; Goodrich et al., 2015), the leopard, clouded leopard and Asiatic black bear are categorized as Vulnerable (Garshelis \& Steinmetz, 2016; Grassman et al., 2016; Stein et al., 2016), and the statuses of the Himalayan wolf and the Himalayan brown bear have not yet been assessed (IUCN, 2016). The remoteness, harsh environment, hilly terrain and inaccessibility of most of the landscape have resulted in inadequate knowledge about the biology of these carnivores in this landscape, especially compared to those in peninsular India (Karanth \& Sunquist, 1995; Karanth \& Nichols, 1998; Karanth et al., 2004). Several camera-trap studies have attempted to estimate carnivore numbers in various parts of the Himalaya, based on unique pelage patterns (Jackson et al., 2006; Datta et al., 2008; Wang \& MacDonald, 2009; Sathyakumar et al., 2011), but with limited success because of harsh environmental conditions and low-density dispersal over large home ranges (Jackson et al., 2006).

Non-invasively collected samples, such as faeces, facilitate ecological, genetic and physiological studies on elusive species without the need to see or disturb the animals. Biomolecules such as DNA or hormone metabolites 


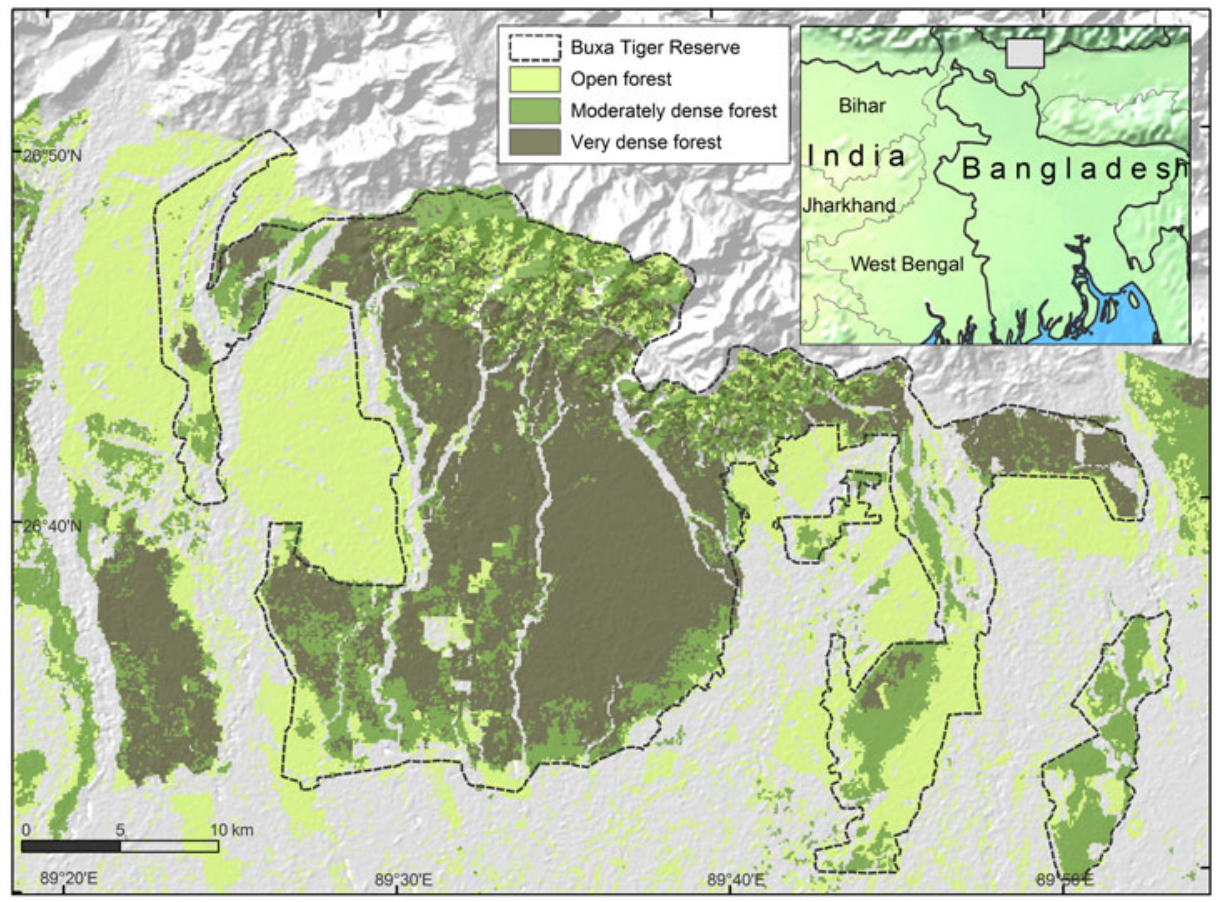

FIG. 1 Buxa Tiger Reserve, West Bengal, India, showing the locations of open forest, moderately dense forest and very dense forest. obtained from faecal samples are informative and can be used to investigate movement (Reddy et al., 2012), mating behaviour (Gour et al., 2013; Reddy et al., 2016), and physiological stress (Bhattacharjee et al., 2015). Genetic tools along with surveys and remote sensing or geographical information systems are promising methods for accurate identification of samples and investigating trends of cryptic carnivores at high altitudes and in harsh conditions. Buxa Tiger Reserve in the north of West Bengal includes both the Himalayan and subtropical zones. The terrain in the Reserve is mostly rugged, and some paths are not accessible by motorized vehicles. We used faecal samples to examine the tiger's feeding habits and habitat selection strategies within the protected area, using molecular and geographical information system tools.

\section{Study area}

Buxa Tiger Reserve (henceforth Buxa), in West Bengal, India, comprises $390.6 \mathrm{~km}^{2}$ of core protected area and a $367.3 \mathrm{~km}^{2}$ buffer zone. It borders Bhutan in the north and Assam in the east (Fig. 1), with tea gardens, agricultural fields and village settlements along its western and southern boundaries. The Reserve lies broadly within the IndoMalayan biogeographical region, which includes three major eco-geographical zones: Central Himalayas, Terai and Bramhaputra flood plains. It spans $60-1,904 \mathrm{~m}$ altitude, with an annual temperature range of $12-32^{\circ} \mathrm{C}$ and estimated mean annual rainfall of $4,100 \mathrm{~mm}$. The habitat is primarily tropical moist-deciduous forest, and sal Shorea robusta is the dominant tree species. There are 37 villages inside the Reserve and 33 tea gardens around its periphery.

\section{Methods}

\section{Sample collection and prey identification}

Trained Buxa forest personnel and volunteers collected faecal samples of large carnivores along forest roads and paths in 2-3 sessions during January-April each year during 2010-2013. A gap of c. 1 month was maintained between consecutive collections in each year. All samples were collected in clean, self-adhesive plastic bags containing silica beads, and geographical locations were recorded with a global positioning system. Samples were transported to the laboratory within 1 month, where they were stored at $-20^{\circ} \mathrm{C}$ until analysis. We extracted DNA from visibly fresh faecal samples by the guanidinium thiocyanate-silica method (Reed et al., 1997) in sets of 10 samples, with an extraction control to monitor for contamination, in a dedicated room free of polymerase chain reaction (PCR) products, to minimize cross-contamination. DNA was not isolated from very dry samples or from samples with fungal growth. Subsequently, all extracts were screened with a tiger-specific PCR assay (Bhagavatula \& Singh, 2006), and prey analysis was conducted on tiger-positive samples.

Tiger faecal samples were washed in a sieve to separate hair and other tissue remains from faecal debris. Prey hair 
TABLE 1 Description of ecological and geographical variables used in ecological niche factor analysis and in habitat suitability analysis using the Mahalanobis distance probability function $\left(D^{2}\right)$ for the tiger Panthera tigris in Buxa Tiger Reserve, India (Fig. 1).

\begin{tabular}{|c|c|c|c|c|}
\hline $\begin{array}{l}\text { Ecological \& } \\
\text { geographical variables }\end{array}$ & Abbreviations & Descriptions & $\begin{array}{l}\text { Value } \\
\text { ranges }\end{array}$ & $\begin{array}{l}\text { Area } \\
\left(\mathrm{km}^{2}\right)\end{array}$ \\
\hline $\begin{array}{l}\text { Agriculture \& human } \\
\text { settlement }^{*}\end{array}$ & Agri\&Hu & $\begin{array}{l}\text { Proportion of agricultural \& human habitation in each } \\
\text { resource unit (Supplementary Material 1) }\end{array}$ & $0-1$ & 28 \\
\hline Dense forest ${ }^{*}$ & DenseF & $\begin{array}{l}\text { Proportion of dense vegetation in each resource unit ( }>40 \% \\
\text { canopy density); vegetation dominated by sal Shorea robusta }\end{array}$ & $0-1$ & 314 \\
\hline Distance to road \& rail line & DistR & Euclidian distance $(\mathrm{m})$ from road network \& rail lines & $0-31415$ & \\
\hline Distance to water & DistW & Euclidian distance $(\mathrm{m})$ from river \& other water sources & $0-4385$ & \\
\hline Elevation & Elev & $\begin{array}{l}\text { Digital elevation data from Advanced Spaceborne Thermal Emission } \\
\text { \& Reflection Radiometer (ASTER) }\end{array}$ & $2-1896$ & \\
\hline Hilly forest ${ }^{*}$ & HillF & Proportion of hilly forest vegetation in each resource unit & $0-1$ & 100 \\
\hline Open forest ${ }^{*}$ & OpenF & $\begin{array}{l}\text { Proportion of open forest vegetation in each resource unit }(<40 \% \\
\text { canopy density) }\end{array}$ & $0-1$ & 244 \\
\hline River \& water & Riv & Proportion of water sources in each resource unit & $0-1$ & 57 \\
\hline $\begin{array}{l}\text { River bed \& riverine } \\
\text { forest }^{*}\end{array}$ & RivB & $\begin{array}{l}\text { Proportion of river bed \& riverine vegetation area in each resource } \\
\text { unit; mainly open type vegetation with rocky outcrops \& wide sandy } \\
\text { river banks; vegetation comprises dry deciduous seral sal, khair } \\
\text { Acacia chundra, sissoo Dalbergia sissoo \& simul Bombax ceiba }\end{array}$ & $0-1$ & 38 \\
\hline Slope & Slop & $\begin{array}{l}\text { Slope in degrees calculated by DEM Surface Tools (Jenness, 2010) in } \\
\text { ArcGIS v. } 9.3\end{array}$ & $0-60.71$ & \\
\hline Sunshine & SunS & Sunshine values calculated by DEM Surface Tools in ArcGIS v. 9.3 & $0-255$ & \\
\hline $\begin{array}{l}\text { Normalized difference } \\
\text { vegetation index }\end{array}$ & NDVI & $\begin{array}{l}\text { NDVI was calculated using red \& infrared bands, using NDVI cal- } \\
\text { culator } 9.1 \text { in ArcGIS v. } 9.3\end{array}$ & $-0.04-0.06$ & \\
\hline
\end{tabular}

${ }^{*}$ Variables were derived from Land Use Land Cover (LULC) classified map (LANDSAT 8, USGS, image LC81380422013349LGNoo).

remains undamaged in carnivore faecal samples and can therefore be used to identify the prey species consumed (Mukherjee et al., 1994; Ramakrishnan et al., 1999; Biswas \& Sankar, 2002; Sankar \& Johnsingh, 2002; Bagchi et al., 2003). At least 20 individual hairs were picked at random from each tiger-positive faecal sample, to prepare permanent slides (Bahuguna et al., 2010). Hair characteristics such as width, cuticular and medullary structures, and medulla to hair width ratio were recorded by microscopic observation. Results were compared with Bahuguna et al. (2010) and with our reference samples.

\section{Analysis of prey occurrence in the tiger's diet}

We tested the stability of the percentage frequency of occurrence of prey in the tiger's diet by randomizing and bootstrapping all samples 999 times in Estimate $S$ v. 8.0.0 (Colwell, 2006). We plotted the percentage frequency of each prey species in the diet cumulatively, at an interval of five faecal samples, and continued the process until all faecal samples were included (Bagchi et al., 2003). We calculated biomass and number of prey individuals consumed by tigers, using Ackerman's equation, $Y=1.980+0.035 X$, where $Y=$ mass of prey $(\mathrm{kg})$ per tiger-positive faecal sample, and $X=$ mean mass of each prey species (Ackerman et al., 1984).

\section{Prey preference analysis}

Prey preference can be calculated as a function of availability for utilization/consumption of prey. We obtained information on large ungulate prey densities (availability) estimated by the Forest Department in 2010 as part of the All India Tiger Monitoring Programme, using line transect surveys and distance sampling methods (data provided by the Forest Department). Prey preference calculations based on frequency of occurrence of prey in faecal samples (utilization) and prey densities were restricted to include only those prey species for which abundance data were available. We used Jacobs' index to determine prey preferences (Hayward et al., 2006a,b, 2012), with the formula $D=\left(r_{i}-\mathrm{p}_{i}\right) /\left(r_{i}+p-2 r_{i} p_{i}\right)$, where $r_{i}$ is the proportion of faecal samples at a study site at which species $i$ is found, and $p_{i}$ is the proportional abundance/density of the given prey species among all prey species found at the site (Jacobs, 1974). The value of Jacobs' index ranges from +1 to -1 , indicating maximum preference and avoidance of prey species, respectively.

\section{Multivariate spatial data analysis}

We assessed 12 eco-geographical variables (Supplementary Fig. $\mathrm{S}_{1}$ ), pairwise, for degree of correlation, and used the 

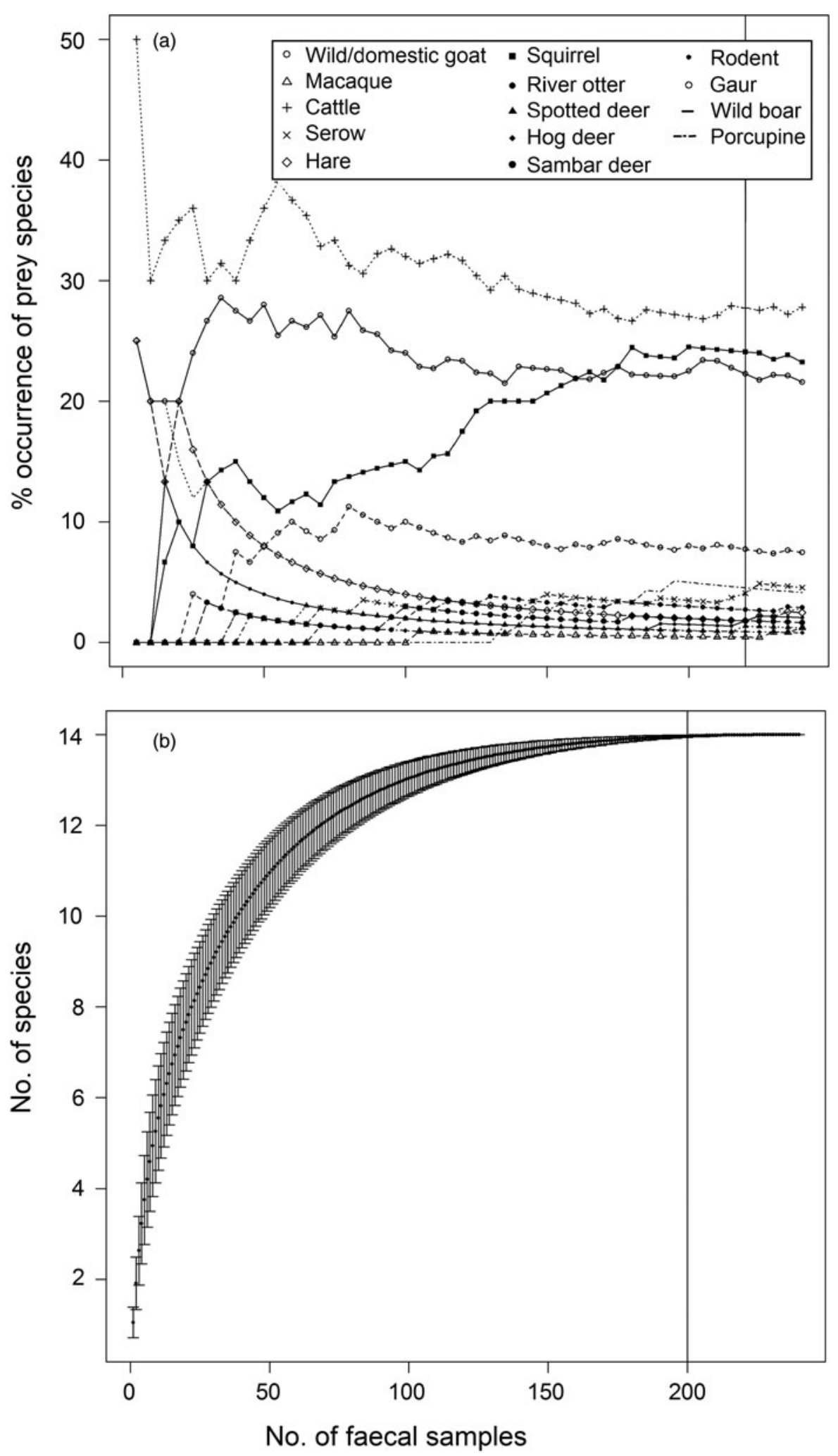

Fig. 2 (a) Percentage frequency of occurrence of prey remains with increasing number of tiger Panthera tigris faecal samples, and (b) diet stabilization curve for tigers in Buxa Tiger Reserve (Fig. 1). locations of tiger-positive samples as indicators of tiger presence. To examine the spatial structure and relationships of these variables we used principal component analysis in the package adehabitat (Calenge, 2006) in $R$ v.3.3.2 ( $\mathrm{R}$ Development Core Team, 2009). We used a multivariate method, ecological niche factor analysis, to understand habitat selection of tigers in Buxa (see Supplementary Material for details of the methods). We used a biplot to visualize the ecological niche available for tigers in Buxa. The biplot projected available and used resource units in 


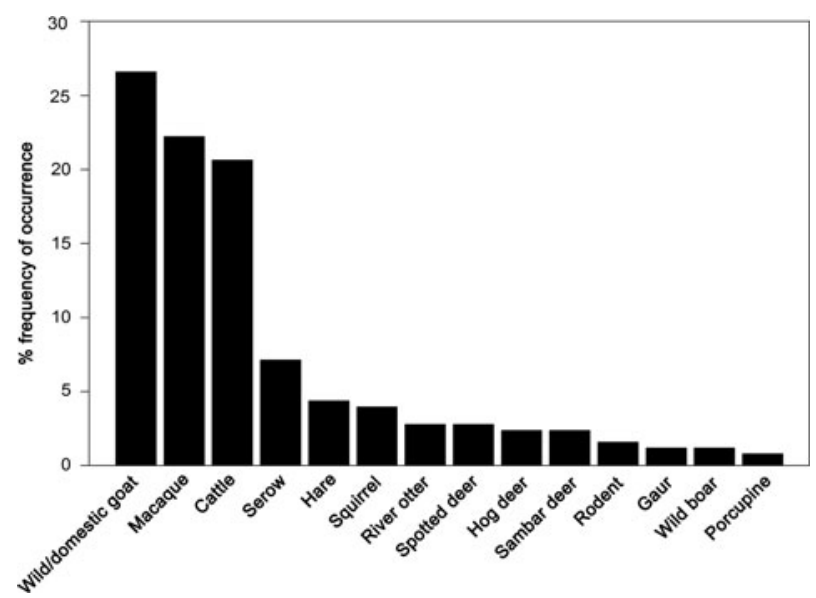

Fig. 3 Percentage frequency of occurrence of prey species in the tiger's diet in Buxa Tiger Reserve (Fig. 1).

the ecological space on the plane defined by marginality and specialization axes (Calenge, 2006; Nawaz et al., 2014).

We computed a habitat suitability map for tigers in Buxa using the Mahalanobis distance statistic $\left(D^{2}\right.$; Clark et al., 1993). This is a measure of dissimilarity between mean habitat characteristics at each resource unit and the mean of habitat characteristics estimated from tiger faecal sample locations. Assuming multivariate normality, $D^{2}$ has a $\chi^{2}$ distribution with $\mathrm{n}$ degrees of freedom $(\mathrm{n}=$ number of ecogeographical variables). The adehabitatHS package implemented in $R$ (Calenge, 2006) facilitates the computation of a map with a continuous gradient of suitability, where each pixel is represented by $\mathrm{P}$ values of $0-1$. We used all ecogeographical variables (Table 1) to construct the gradient of this habitat suitability map. We used Boyce's index to categorize the gradient habitat suitability map into 15 classes (with 0.06 intervals), and calculated predicted-to-expected ratios $\left(F_{i}\right)$ for each class using the formula $F_{i}=p_{i} / E_{i}$, where $p_{i}$ is the predicted frequency of evaluation points in class $i$, and $E_{i}$ is expected frequency expressed as relative area covered by each class (Hirzel et al., 2006). $E_{i}$ was plotted against class intervals and the suitability map was reclassified into three classes (poor, suitable and high quality) by choosing threshold points from the $F_{i}$ curve. $F_{i}=1$ indicates a random model where presence is equal to that expected by chance. This point was taken as the boundary between poor $\left(F_{i}<1\right)$ and suitable $\left(F_{i}>1\right)$ habitats (Hirzel et al., 2006).

\section{Results}

\section{Analysis of prey occurrence in the tiger's diet}

In total 909 faecal samples were collected in Buxa during 2010-2013, of which 372 were found to be of tiger origin. Fourteen prey species/groups were identified in 240 genetically identified tiger faecal samples. We did not attempt to

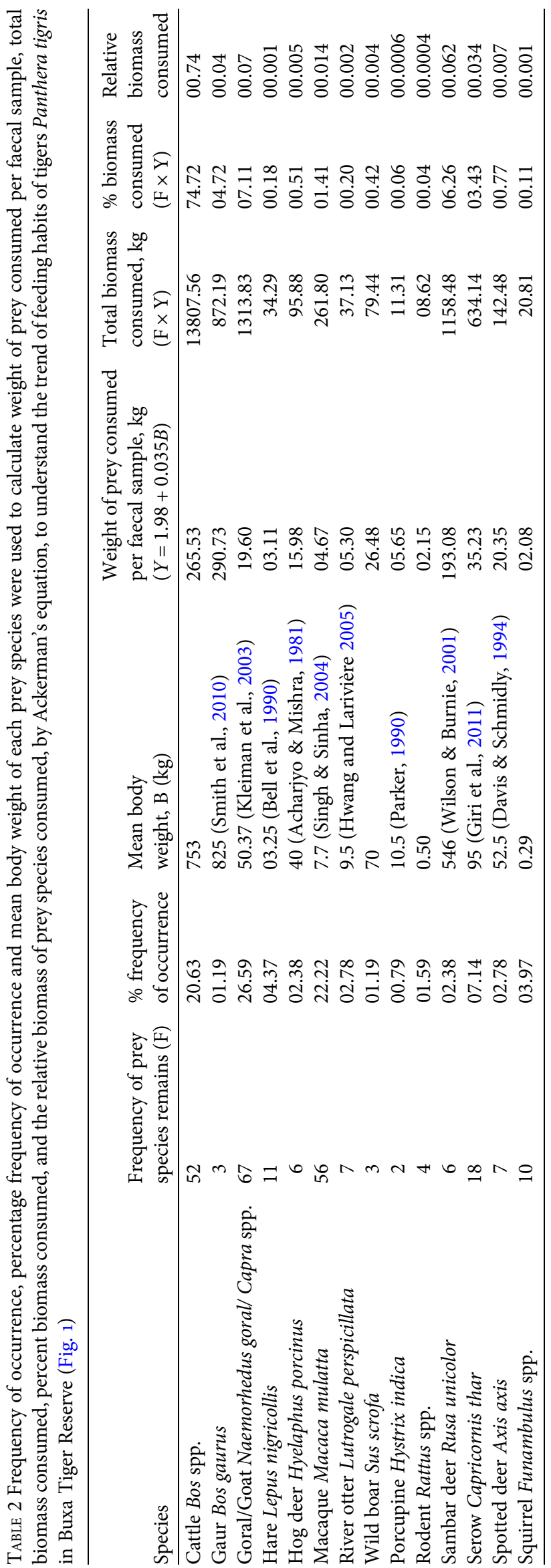


distinguish between wild and domestic goat species, and most samples were identified only to the generic level. Proportions of various prey species in faecal samples stabilized on analysing 220 samples (Fig. 2a). The species diversity index indicated that no new prey species were identified after analysing 200 samples (Fig. 2 b). The percentage frequency of occurrence of prey species in tiger faecal samples is presented in Fig. 3, and the biomass contribution of each prey species is in Table 2. Goats Capra spp. were the most prevalent prey in the samples (26.59\%), followed by macaques Macaca mulatta (22.22\%) and cattle Bos spp. (20.63\%). Porcupines Hystrix indica contributed the least $(0.79 \%)$ to the tiger's diet.

\section{Prey preference analysis}

Out of the fourteen prey species identified in tiger faecal samples, prey preference analysis was restricted to six tiger prey species (hog deer Axis porcinus, sambar deer Rusa unicolor, spotted deer Axis axis, wild boar Sus scrofa, Indian gaur Bos gaurus and cattle Bos spp.) for which abundance data were available. Amongst these, the most preferred prey species according to Jacobs' index were hog deer Axis porcinus, sambar deer Rusa unicolor and spotted deer Axis axis (Fig. 4). Cattle Bos spp., wild boar Sus scrofa and Indian gaur Bos gaurus were found to be the less preferred prey species (Fig. 4).

\section{Landscape}

Buxa comprises $40 \%$ densely vegetated forests, $31 \%$ open forests and $13 \%$ hill forests, with large areas also encompassing riverine forests (5\%), and water channels and rivers (7\%). The southern part of the Reserve is relatively flat, with $0-45^{\circ}$ slopes, whereas the northern peripheral areas have steep slopes of up to $66^{\circ}$. Principal component analysis yielded a high normalized difference vegetation index value, and dense forests are mostly found around water channels. Hilly forests correlate with steep slopes to the north (Fig. 5). Although roads and railways cut across the Reserve, they occur away from dense vegetation. Agricultural areas, human settlements and tea gardens surround the Reserve except in the northern hilly parts, which are usually adjoined by open forest areas (Fig. 5).

\section{Ecological niche factor analysis}

Hilly forests, higher elevations and steep slopes show the highest coefficients of marginality, indicating that tigers avoid highland vegetation at high elevations and on steep slopes (Table 3). The marginality factor also indicates a selection for dense vegetation, dense forests, open forests, riverine vegetation and areas close to water sources such as rivers, streams and ponds, and avoidance of man-made

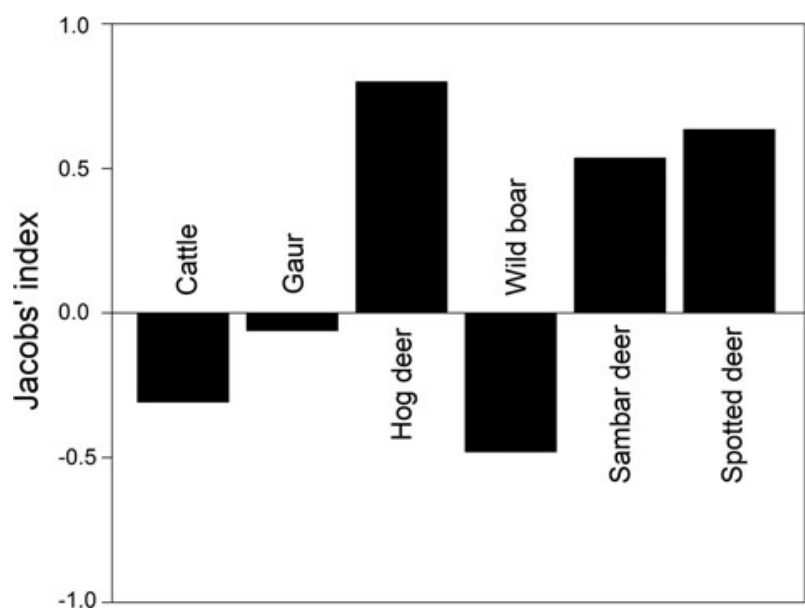

FIG. 4 Jacobs' index values (see text for details) of prey preferences of tigers in Buxa Tiger Reserve (Fig. 1). Of the 14 prey species identified in tiger faecal samples (Fig. 3), this analysis was restricted to the six tiger prey species for which abundance data were available.

land-use infrastructures. The specialization factor (niche width) implies that the ecological niche of tigers in Buxa is much narrower than the available variation in habitat components. Elevation, slope, sunshine and hilly forests were the most prominent variables affecting the niche width for tigers, which have a preference for low elevations, and gentle slopes with minimal human footprint (Fig. 6).

\section{Habitat suitability}

A Pearson correlation test with all eco-geographical variables indicated that elevation, slope and hilly forests are highly correlated with each other (Table 4). Hilly forests and slope were therefore excluded to minimize bias in the habitat suitability map based on Mahalanobis distance statistics. This map (Fig. 7) indicates that tiger habitat is not distributed uniformly throughout Buxa. The $F_{i}$ values of 0.50-3.86 derived from Boyce's index (Supplementary Fig. S2) indicate the habitat suitability map has good predictive power for the occurrence of tigers in Buxa. Approximately $62 \%$ of the protected area is classified as suitable, with 21,23 and $17 \%$ classified as moderately suitable, suitable and highly suitable, respectively.

\section{Discussion}

The survival and persistence of large carnivores in an area depend mainly on the availability of prey and undisturbed, protected habitat. Environmental harshness and rugged terrain make it difficult to carry out systematic field surveys in Himalayan habitats and to gather information about quality of habitat and availability of food (Jackson et al., 2006; 


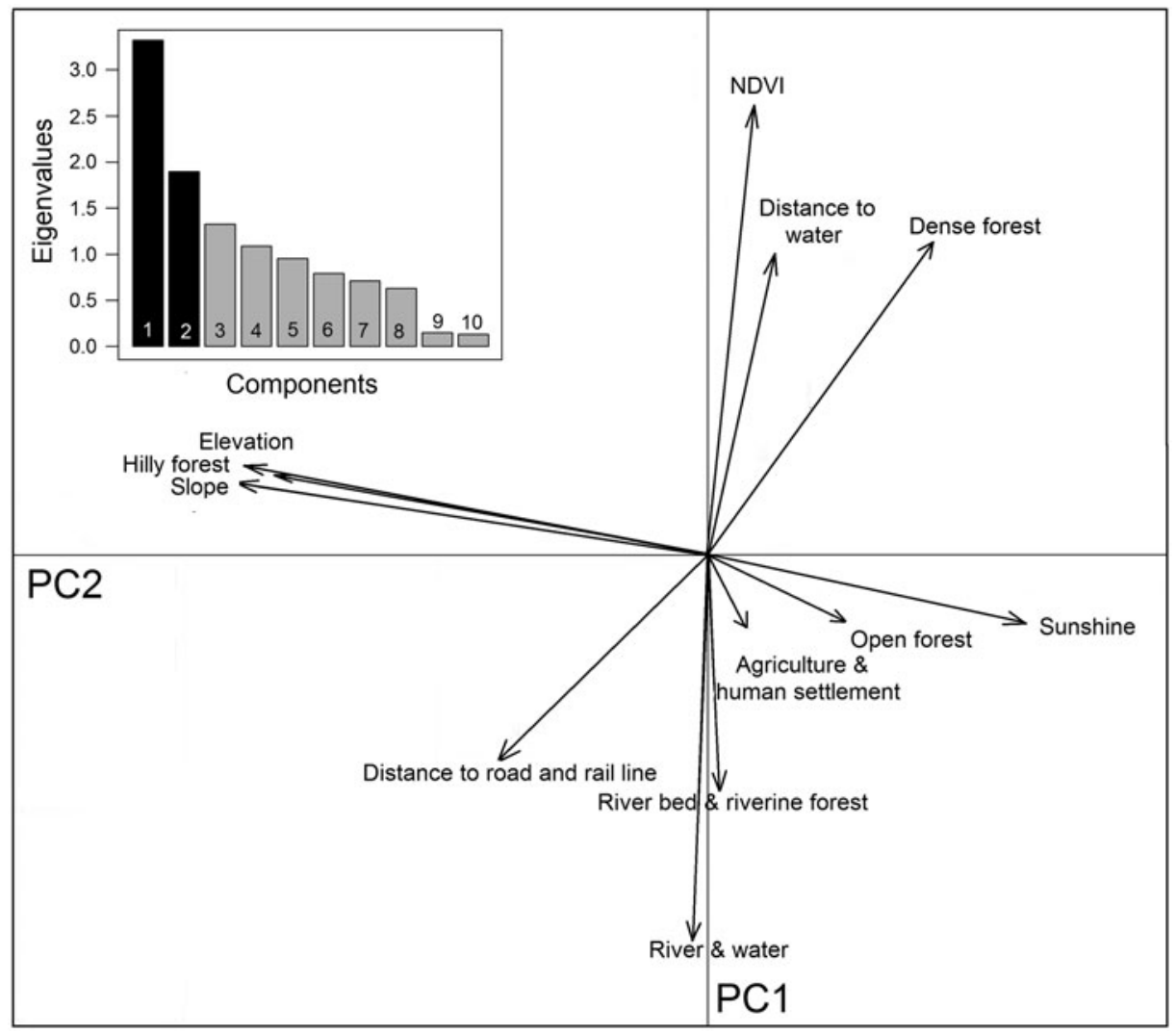

FIG. 5 Loading plot of the first two principal components depicting relationships among 12 ecological and geographical variables (Table 3) in Buxa Tiger Reserve (Fig. 1). Eigenvalues of the first 10 principal components are indicated on the bar chart.
TABLE 3 Ecological niche factor analysis of tiger habitat in Buxa Tiger Reserve (Fig. 1), using locations of tiger faecal samples as the response variable. Marginality indicates the direction in which the species' niche varies from mean available conditions in the area. Specialization is a measure of niche width within the available habitat.

\begin{tabular}{lcc}
\hline $\begin{array}{l}\text { Habitat variables } \\
\text { Agriculture \& human }\end{array}$ & $\begin{array}{c}\text { 1st Specialization } \\
\text { axis }\end{array}$ \\
\hline $\begin{array}{l}\text { settlement } \\
\text { Dense forest }\end{array}$ & 0.03 \\
Distance to road \& rail line & -0.17 & 0.03 \\
Distance to water & -0.11 & -0.05 \\
Elevation & -0.44 & 0.05 \\
Hilly forest & -0.55 & 0.86 \\
Open forest & 0.23 & -0.28 \\
River & -0.08 & 0.08 \\
Riverbed \& riverine forest & 0.23 & 0.10 \\
Slope & -0.41 & 0.09 \\
Sunshine & 0.27 & -0.28 \\
NDVI $^{2}$ & 0.16 & 0.20 \\
\hline
\end{tabular}

${ }^{1}$ Positive values indicate selection; negative values indicate avoidance. ${ }^{2}$ Normalized Difference Vegetation Index.

Sathyakumar et al., 2011). Location and analysis of faecal samples yield invaluable information on ecological, genetic and physiological parameters, which can be utilized for managing mega-predators in such terrains. Repeated surveys in Buxa were made possible by recruiting Forest Department staff and training them to conduct simple foot patrol-based field surveys.

We used molecular tools to identify tiger faecal samples, accurately differentiating them from those of sympatric carnivores such as leopards and clouded leopards. Prey remains in carnivore faecal samples can be identified by several methods, including microscopic hair analysis and DNA-based species identification. Although more accurate, DNA analysis of prey remains in a large number of samples by next-generation sequencing (Shehzad et al., 2012) or denaturing gradient gel electrophoresis (Lee et al., 2013) is more costly and technique-intensive. Microscopy of hair samples provides reliable identification at least to genus, and in many cases to the species level. Population density and biomass of large herbivore species have often been used to assess the carnivore carrying capacity of various habitats. Biological modelling by Karanth et al. (2004) demonstrated that prey depletion can lead to significant declines in tiger populations, and thus population sizes of prey and predators are interdependent.

We identified 14 prey species by microscopic analysis of hair remains in tiger faecal samples (Fig. 3). These were the tiger's utilized prey in Buxa. However, only a few of the tiger's larger prey species are surveyed regularly (by the Forest Department), and we could use only these data in computing Jacobs' index for prey selectivity (goats and macaques, 


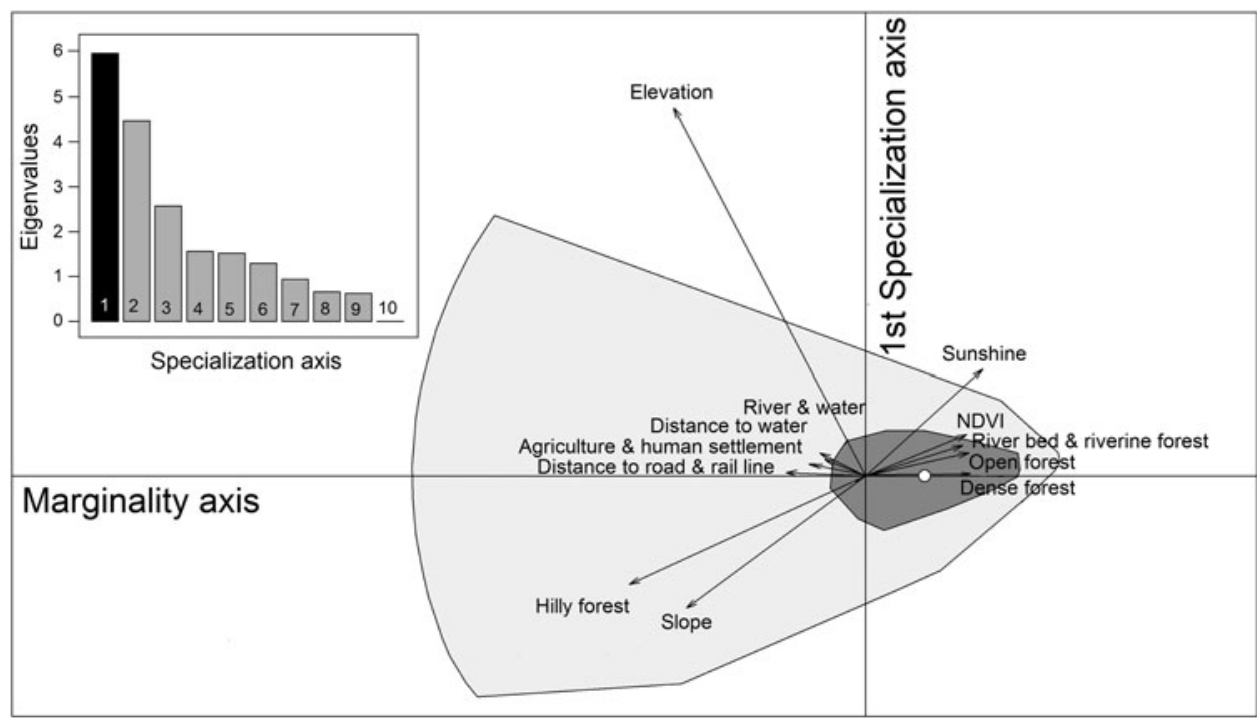

FIG. 6 Biplot of the ecological niche factor analysis of tiger habitat in Buxa Tiger Reserve (Fig. 1). The pale shaded area represents available habitat and the darker area corresponds to the tiger's ecological niche, with the barycentre of the niche indicated by an unfilled circle on the $\mathrm{x}$-axis. The distance between the barycentre of the niche and the barycentre of available conditions (intersection of the two axes) represents the marginality of the niche within the available habitat.

Eigenvalues of the first 10 specialization axes are indicated in the bar chart.

which are abundant in Buxa, are not counted in the Forest Department line transect surveys). Contrary to previous studies on tiger feeding habits, in which tigers were found to prey heavily on medium- to large-sized wild cervids (Biswas \& Sankar, 2002; Kapfer et al., 2011), our results show that tigers in Buxa consume mostly small prey, such as goats and macaques (Fig. 3). Because of the very low abundance of primary wild prey such as large cervids, tigers in Buxa also appear to depend heavily on domestic cattle. However, their preferred prey (hog deer, sambar deer and spotted deer) as suggested by Jacobs' index (Fig. 4) is the same as reported elsewhere (Biswas \& Sankar, 2002; Kapfer et al., 2011; Hayward et al., 2012). High frequency of occurrence of cattle hair in the faecal samples reflects the abundance of this species in the landscape, and similarly the low frequencies of occurrence of wild ungulate species such as hog deer, sambar deer and spotted deer in the faecal samples reflects their rarity in the landscape. Frequency of prey species occurrence in tiger faecal samples and Jacobs' index together indicate that the tiger's preferred wild prey species occurred the least in tiger faecal samples. Low tiger numbers in Buxa could be attributed to the low numbers of the tiger's major prey species, and this matter needs to be addressed urgently by park managers. We believe that tiger augmentation/reintroduction programmes in Buxa and elsewhere will only succeed if park managers ensure reduction in cattle numbers in core protected areas and work towards increasing wild ungulate abundance by improving grasslands, protection and law enforcement.

Repeated surveys over a large area and spanning long timescales ensure greater accuracy of data (Kapfer et al., 2011). The percentage occurrence of prey species stabilized after we analysed 220 scats (Fig. 2b), thus ensuring that we identified even rare prey species (Table 2). Pseudo- replication (Hurlbert, 1984) and biased estimates of the relative importance of certain prey (Marucco et al., 2008; Kapfer et al., 2011) were overcome by collecting samples in multiple sessions.

We assessed how a species selects a particular habitat by incorporating several continuous eco-geographical variables in robust multivariate analyses and using the locations of tiger-positive faecal samples as indicators of tiger presence. These methods do not require independence of the explanatory variables (contrary to generalized linear models) and prior assumptions about which variables may be important for the target species (Hirzel et al., 2002), or absence data of target species, making them more precise tools for studies based in difficult terrain. The suitability map of Buxa Tiger Reserve generally follows the productivity pattern of the Reserve, with the central and eastern areas mapped as highly suitable $(17 \%)$ and moderately suitable (23\%) for tigers, respectively (Fig. 7). These regions are also part of the administrative core area of the Reserve. The eastern part has suitable habitat (e.g. dense forests), availability of water and low human disturbance (Fig. 1). The mountainous northern area, although undisturbed, is not preferred by tigers. However, this result should be viewed with caution as the northern part has fewer paths and steep slopes, constraining foot-patrol surveys and detection of tiger faecal samples.

Low carnivore detectability, high anthropogenic pressure and rapid degradation of habitat disturb ecological balances throughout the Himalayas. In Buxa the ecosystem is threatened by dolomite mining, cane and bamboo harvesting, timber felling and cattle grazing. Cattle grazing and fuelwood collection are known to lead to fragmentation of wildlife habitat (Liu et al., 2001), decline of wildlife populations (Aigner et al., 1998; Hall \& Farrell, 2001), and loss of 
TABLE 4 Pearson correlation coefficients among ecological and geographical variables (Table 1) used in ecological niche factor analysis and in habitat suitability analysis using the Mahalanobis distance probability function $\left(D^{2}\right)$.

\begin{tabular}{|c|c|c|c|c|c|c|c|c|c|c|c|c|}
\hline & $\begin{array}{l}\text { Agriculture \& } \\
\text { human settlement }\end{array}$ & $\begin{array}{l}\text { Dense } \\
\text { forest }\end{array}$ & $\begin{array}{l}\text { Distance to } \\
\text { road \& rail line }\end{array}$ & $\begin{array}{l}\text { Distance } \\
\text { to water }\end{array}$ & Elevation & $\begin{array}{l}\text { Hilly } \\
\text { forest }\end{array}$ & $\begin{array}{l}\text { Open } \\
\text { forest }\end{array}$ & River & $\begin{array}{l}\text { Riverbed \& } \\
\text { riverine } \\
\text { forest }\end{array}$ & Slope & Sunshine & $\mathrm{NDVI}^{2}$ \\
\hline $\begin{array}{l}\text { Agriculture \& human } \\
\text { settlement }\end{array}$ & 1 & & & & & & & & & & & \\
\hline Dense forest & -0.17 & 1 & & & & & & & & & & \\
\hline Distance to road \& rail line & -0.06 & -0.32 & 1 & & & & & & & & & \\
\hline Distance to water & 0.05 & 0.29 & -0.17 & 1 & & & & & & & & \\
\hline Elevation & -0.10 & -0.27 & 0.26 & -0.00 & 1 & & & & & & & \\
\hline Hilly forest & -0.07 & -0.35 & 0.21 & -0.00 & $0.87^{1}$ & 1 & & & & & & \\
\hline Open forest & -0.13 & -0.47 & 0.05 & -0.05 & -0.29 & -0.30 & 1 & & & & & \\
\hline River & -0.05 & -0.27 & 0.18 & -0.31 & -0.08 & -0.11 & -0.19 & 1 & & & & \\
\hline Riverbed \& riverine forest & -0.05 & -0.24 & 0.09 & -0.24 & -0.09 & -0.10 & -0.09 & 0.06 & 1 & & & \\
\hline Slope & -0.09 & -0.29 & 0.22 & -0.06 & $0.84^{1}$ & $0.84^{1}$ & -0.26 & -0.06 & -0.07 & 1 & & \\
\hline Sunshine & 0.04 & 0.15 & -0.12 & 0.01 & -0.41 & -0.40 & 0.09 & 0.05 & 0.04 & -0.52 & 1 & \\
\hline $\mathrm{NDVI}^{2}$ & -0.22 & 0.44 & -0.25 & 0.33 & 0.05 & 0.06 & 0.11 & -0.72 & -0.30 & 0.02 & -0.04 & 1 \\
\hline
\end{tabular}

${ }^{1}$ Multi-collinearity among eco-geographical variables can result in over-fitting in habitat suitability modelling (Graham 2003; Pearson et al., 2007). We therefore excluded highly correlated environmental predictors (hilly forests, slope) from the Mahalanobis distance probability analysis used to predict suitable habitat for tigers.

${ }^{2}$ Normalized Difference Vegetation Index 


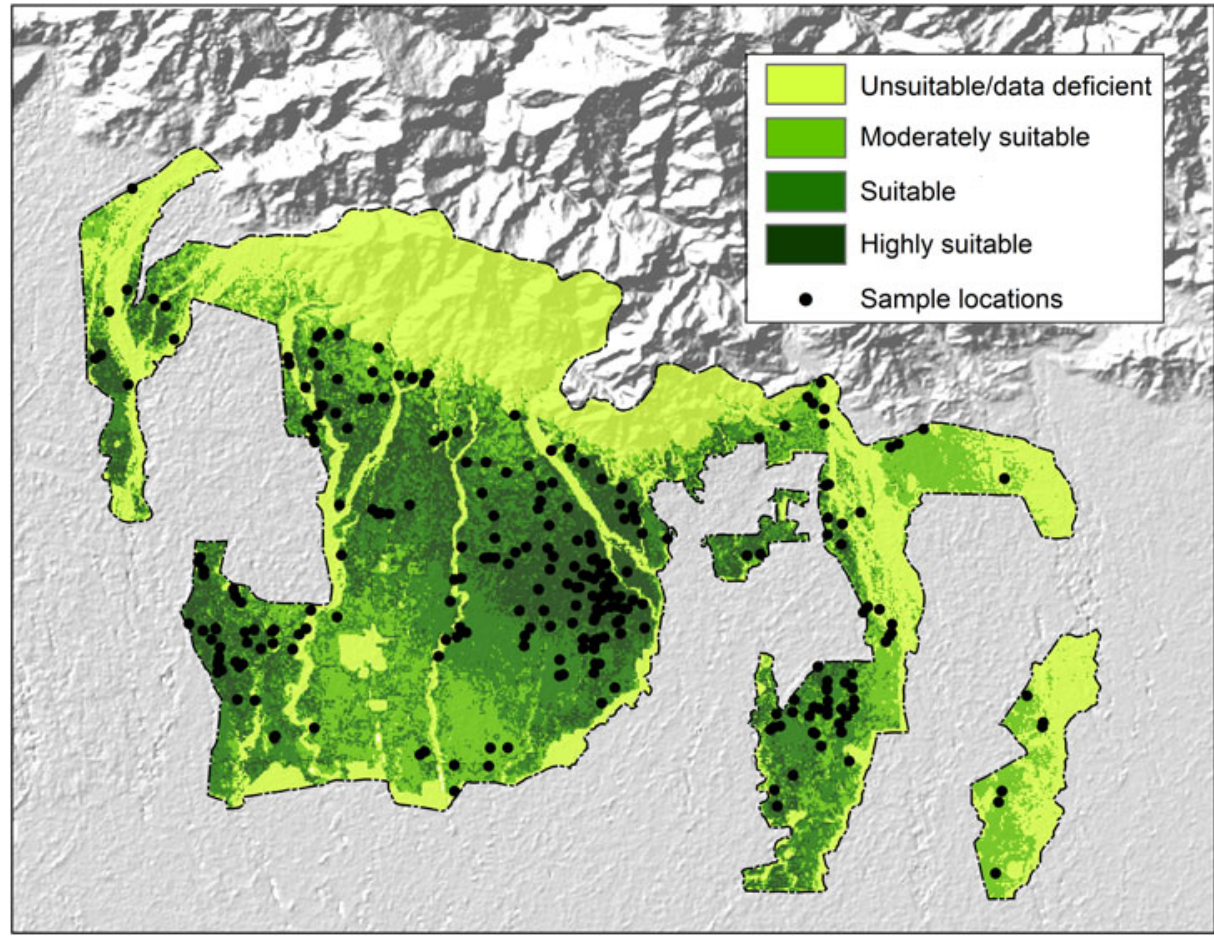

Fig. 7 Habitat suitability map for tigers in Buxa Tiger Reserve (Fig. 1), with locations where tiger faecal samples were collected. biodiversity (Rosenstock, 1998; Sagar \& Singh, 2004). The low detectability of tigers in Buxa may be a result of the low density of preferred wild ungulate prey species and high levels of human disturbance (Sinha \& Das, 2003; Das, 2008; Sarkar \& Das, 2012). The tiger's preference for dense canopy cover, especially near water bodies, with a low human footprint, means that only a small proportion of the Reserve is highly suitable habitat for the tiger.

Empirical data generated with simple laboratory-based technologies in combination with field surveys can be used effectively to guide park management. This study is the first intensive effort to examine the status and feeding habits of tigers in Buxa, and provides a baseline for future studies in this and similar protected areas.

\section{Acknowledgements}

We gratefully acknowledge the logistic support provided by Dr R. P. Saini, Field Director of Buxa Tiger Reserve. We thank Dr Martin Fisher and two anonymous referees for their constructive comments which have greatly improved the manuscript. The study was funded by the Department of Biotechnology and the Council of Scientific and Industrial Research of the Government of India.

\section{Author contributions}

MSS and PAR designed the study, carried out analyses, interpreted the results and wrote the article. HS, SM and KS carried out DNA and hair analyses. JVB and RJ coordinated and supervised field work and sample collection. SS contributed to the analyses and writing. All authors read and agreed to the final draft.

\section{References}

Acharjyo, L.N. \& Mishra, C.G. (1981) Notes on weight and size at birth of eight species of Indian wild ungulates in captivity. Journal of the Bombay Natural History Society, 78, 373-375.

Ackerman, B.B., Lindzey, F.G. \& Hemker, T.P. (1984) Cougar food habits in southern Utah. The Journal of Wildlife Management, 48, 147-155.

Aigner, P.A., Block, W.M. \& Morrison, M.L. (1998) Effect of firewood harvesting on birds in a California oak-pine woodland. The Journal of Wildlife Management, 62, 485-496.

Bagchi, S., Goyal, S.P. \& Sankar, K. (2003) Prey abundance and prey selection by tigers (Panthera tigris) in a semi-arid, dry deciduous forest in western India. Journal of Zoology, 260, 285-29o.

Bahuguna, A., Sahajpal, V., Goyal, S.P., Mukherjee, S.K. \& Thakur, V. (2010) Species Identification from Guard Hair of Selected Indian Mammals: A Reference Guide. Wildlife Institute of India, Dehradun, India.

Bell, D.J., Oliver, W.L.R. \& Ghose, R.K. (1990) The hispid hare Caprolagus hispidus. In Rabbits, Hares and Pikas: Status Survey and Conservation Action Plan (eds J.A. Chapman \& J.E.C. Flux), pp. 128136. IUCN, Gland, Switzerland.

Bhagavatula, J. \& Singh, L. (2006) Genotyping faecal samples of Bengal tiger (Panthera tigris tigris) for population estimation: a pilot study. BMC Genetics, 7, 48.

Bhattacharjee, S., Kumar, V., Chandrasekhar, M., Malviya, M., Ganswindt, A., Ramesh, K. et al. (2015) Glucocorticoid stress responses of reintroduced tigers in relation to anthropogenic disturbance in Sariska Tiger Reserve in India. PLoS One, 10(6), eo127626. 
Biswas, S. \& Sankar, K. (2002) Prey abundance and food habit of tigers (Panthera tigris tigris) in Pench National Park, Madhya Pradesh, India. Journal of Zoology, 256, 411-420.

Calenge, C. (2006) The package "adehabitat" for the R software: a tool for the analysis of space and habitat use by animals. Ecological Modelling, 197, 516-519.

Clark, J.D., Dunn, J.E. \& Smith, K.G. (1993) A multivariate model of female black bear habitat use for a geographic information system. The Journal of Wildlife Management, 57, 519-526.

Colwell, R.K. (2006) Programme Estimate $S$ v. 8.o.o. University of Connecticut, Storrs, USA.

DAs, B.K. (2008) The policy of reduction of cattle populations from protected areas: a case study from Buxa Tiger Reserve, India. Conservation \& Society, 6, 185-189.

Datta, A., Anand, M.O. \& Naniwadekar, R. (2008) Empty forests: large carnivore and prey abundance in Namdapha National Park, north-east India. Biological Conservation, 141, 1429-1435.

Davis, W.B. \& Schmidiy, D.J. (1994) Axis deer. In The Mammals of Texas Online Edition. http://www.nsrl.ttu.edu/tmot1/cervaxis.htm [accessed 17 August 2016].

Dinerstein, E. \& Mehta, J.N. (1989) The clouded leopard in Nepal. Oryx, 23, 199-201.

Fox, J.L., Sinha, S.P., Chundawat, R.S. \& Das, P.K. (1991) Status of the snow leopard Panthera uncia in northwest India. Biological Conservation, 55, 283-298.

Garshelis, D. \& S teinmetz, R. (2016) Ursus thibetanus. In The IUCN Red List of Threatened Species 2016: e.T22824A45034242. Http://dx. doi.org/10.2305/IUCN.UK.2016-3.RLTS.T22824A45034242.en [accessed 3 February 2017].

Giri, S., Aryal, A., Koirala, R.K., Adhikari, B. \& Raubenheimer, D. (2011) Feeding ecology and distribution of Himalayan serow (Capricornisthar) in Annapurna Conservation Area, Nepal. World Journal of Zoology, 6, 80-85.

Goodrich, J., Lynam, A., Miquelle, D., Wibisono, H., Kawanishi, K., Pattanavibool, A. et al. (2015) Panthera tigris. In The IUCN Red List of Threatened Species 2015: e.T15955A50659951. Http://dx.doi.org/10.2305/IUCN.UK.2015-2.RLTS.T15955A50659951. en [accessed 3 February 2017].

Gour, D.S., Bhagavatula, J., Bhavanishankar, M., Reddy, P.A., Gupta, J.A., SArkar, M.S. et al. (2013) Philopatry and dispersal patterns in tiger (Panthera tigris). PLoS ONE, 8(7), e66956.

Graham, M.H. (2003) Confronting multicollinearity in ecological multiple regression. Ecology, 84, 2809-2815.

Grassman, L., Lynam, A., Mohamad, S., Duckworth, J.W., Bora, J., Wilcox, D. et al. (2016) Neofelis nebulosa. In The IUCN Red List of Threatened Species 2016: e.T14519A9721509o. Http://dx.doi.org/10. 2305/IUCN.UK.2016-1.RLTS.T14519A97215090.en [accessed 3 February 2017].

Hall, T.E. \& Farrell, T.A. (2001) Fuelwood depletion at wilderness campsites: extent and potential ecological significance.

Environmental Conservation, 28, 241-247.

Hayward, M.W., Henschel, P., O’Brien, J., Hofmeyr, M., Balme, G. \& Kerley, G.I.H. (2006a) Prey preferences of the leopard (Panthera pardus). Journal of Zoology, 270, 298-313.

Hayward, M.W., Jędrzejewski, W. \& Jedrzejewska, B. (2012) Prey preferences of the tiger Panthera tigris. Journal of Zoology, 286, 221-231.

Hayward, M.W., O’Brien, J., Hofmeyr, M. \& Kerley, G.I.H. (2006b) Prey preferences of the African wild dog Lycaon pictus (Canidae: Carnivora): ecological requirements for conservation. Journal of Mammalogy, 87, 1122-1131.

Hirzel, A.H., Hausser, J., Chessel, D. \& Perrin, N. (2002) Ecological-niche factor analysis: how to compute habitat-suitability maps without absence data? Ecology, 83, 2027-2036.
Hirzel, A.H., Lay, G.L., Helfer, V., Randin, C. \& Guisan, A. (2006) Evaluating the ability of habitat suitability models to predict species presences. Ecological Modelling, 199, 142-152.

Hurlbert, S.H. (1984) Pseudo replication and the design of ecological field experiments. Ecological Monographs, 54, 187-211.

Hutchinson, G.E. (1957) Concluding remarks. Cold Spring Harbor Symposia on Quantitative Biology, 22, 415-427.

Hwang, Y.T. \& Larivière, S. (2005) Lutrogale perspicillata. Mammalian Species, 786, 1-4, http://dx.doi.org/10.1644/786.1.

IUCN (2016) The IUCN Red List of Threatened Species 2016-3. Http:// www.iucnredlist.org [accessed 3 February 2017].

Jackson, R., Mallon, D., McCarthy, T., Chundaway, R.A. \& Навів, B. (2008) Panthera uncia. In The IUCN Red List of Threatened Species 2008: e.T22732A9381126. Http://dx.doi.org/10. 2305/IUCN.UK.2008.RLTS.T22732A9381126.en [accessed 3 February 2017].

Jackson, R.M., Roe, J.D., Wangchuk, R. \& Hunter, D.O. (2006) Estimating snow leopard population abundance using photography and capture-recapture techniques. Wildlife Society Bulletin, 34, 772-781.

JАСовS, J. (1974) Quantitative measurement of food selection. Oecologia, 14, 413-417.

Jenness, J. (2010) DEM Surface Tools v. 2.1. 254. Jenness Enterprises, Flagstaff, USA. Http://www.jennessent.com/arcgis/surface_area. htm [accessed 5 January 2012].

Kapfer, P.M., Streby, H.M., Gurung, B., Simcharoen, A., McDougal, C.C. \& Smith, J.L.D. (2011) Fine-scale spatio-temporal variation in tiger Panthera tigris diet: effect of study duration and extent on estimates of tiger diet in Chitwan National Park, Nepal. Wildlife Biology, 17, 277-285.

Karanth, K.U., Chundawat, R.S., Nichols, J.D. \& Kumar, N.S. (2004) Estimation of tiger densities in the tropical dry forests of Panna, Central India, using photographic capture-recapture sampling. Animal Conservation, 7, 285-290.

KarAnth, K.U. \& Nichols, J.D. (1998) Estimation of tiger densities in India using photographic captures and recaptures. Ecology, 79, 2852-2862.

Karanth, K.U. \& Sunquist, M.E. (1995) Prey selection by tiger, leopard and dhole in tropical forests. Journal of Animal Ecology, 64, 439-450.

Kleiman, D.G., Geist, V. \& McDade, M.C. (eds) (2003) Bovids VI: Sheep, goats, and relatives (Caprinae). In Grzinek's Animal Life Encyclopedia, Volume 16, 2nd edition (ed. M. Hutchins), pp. 87-98. Thomson-Gale Publishing, Detroit, USA.

Lee, O., Lee, S., Nam, D.-H. \& Lee, H.Y. (2013) Molecular analysis for investigating dietary habits: genetic screening of prey items in scat and stomach contents of leopard cats Prionailurus bengalensis euptilurus. Zoological Studies, 52, 45, http://dx.doi.org/10.1186/ 1810-522X-52-45.

LimA, S.L. (1998) Nonlethal effects in the ecology of predator-prey interactions. BioScience, 48, 25-34.

Liu, J., Linderman, M., Ouyang, Z., An, L., Yang, J. \& Zhang, H. (2001) Ecological degradation in protected areas: the case of Wolong Nature Reserve for giant pandas. Science, 292, 98-101.

Manly, B.F., Macdonald, L., Thomas, D., Macdonald, T.L. \& ERICKSON, W.P. (2002) Resource Selection by Animals: Statistical Design and Analysis for Field Studies, 2nd edition. Kluwer Academic Publishers, London, UK.

Marucco, F., Pletscher, D.H. \& Boitani, L. (2008) Accuracy of scat sampling for carnivore diet analysis: wolves in the Alps as a case study. Journal of Mammalogy, 89, 665-673.

Menge, B.A. (1995) Indirect effects in marine rocky intertidal interaction webs: patterns and importance. Ecological Monographs, $65,21-74$ 
Menge, B.A. (1997) Detection of direct versus indirect effects: were experiments long enough? The American Naturalist, 149, 801-823.

Mishra, C. (1997) Livestock depredation by large carnivores in the Indian trans-Himalaya: conflict perceptions and conservation prospects. Environmental Conservation, 24, 338-343.

Mishra, C., Madhusudan, M.D. \& Datta, A. (2006) Mammals of the high altitudes of western Arunachal Pradesh, eastern Himalaya: an assessment of threats and conservation needs. Oryx, 40, 29-35.

Mukherjee, S., Goyal, S.P. \& Chellam, R. (1994) Refined techniques for the analysis of Asiatic lion Panthera leo persica scats. Acta Theriologica, 39, 425-430.

Nawaz, M.A., Martin, J. \& Swenson, J.E. (2014) Identifying key habitats to conserve the threatened brown bear in the Himalaya. Biological Conservation, 170, 198-206.

Parker, S.B. (1990) Grzimek's Encyclopedia of Mammals, Volume 4. McGraw-Hill, New York, USA.

Pearson, R.G., Raxworthy, C.J., Nakamura, M. \& Townsend Peterson, A. (2007) Predicting species distributions from small numbers of occurrence records: a test case using cryptic geckos in Madagascar. Journal of Biogeography, 34, 102-117.

Perrin, N. (1984) Contribution a l'ecologie du genre Cepaea (Gastropoda): Approche descriptive etexperimentale de l'habitat et de la niche ecologique. $\mathrm{PhD}$ thesis. University of Lausanne, Lausanne, Switzerland.

Polis, G.A. (1999) Why are parts of the world green? Multiple factors control productivity and the distribution of biomass. Oikos, 86, 3-15.

Polis, G.A. \& HURD, S.D. (1996) Allochthonous input across habitats, subsidized consumers and apparent trophic cascades: examples from the ocean-land interface. In Food Webs: Integration of Patterns and Dynamics (eds G. Polis \& K. Winemiller), pp. 275-285. Chapman \& Hall, New York, USA.

Polis, G.A. \& Strong, D.R. (1996) Food web complexity and community dynamics. The American Naturalist, 147, 813-846.

R Development Core Team (2009) R: A Language and Environment for Statistical Computing. R Foundation for Statistical Computing, Vienna, Austria.

Ramakrishnan, U., Coss, R.G. \& Pelkey, N.W. (1999) Tiger decline caused by the reduction of large ungulate prey: evidence from a study of leopard diets in southern India. Biological Conservation, 89, 113-120.

Reddy, P.A., Gour, D.S., Bhavanishankar, M., Jaggi, K., Hussain, S.M., Harika, K. \& Shivaji, S. (2012) Genetic evidence of tiger population structure and migration within an isolated and fragmented landscape in northwest India. PLoS ONE, 7(1), e29827.

Reddy, P.A., Ramesh, K., Sarkar, M.S., Srivastava, A., Bhavanishankar, M. \& Shivaji, S. (2016) Significance of mate selection and adult sex ratio in tiger reintroduction/reinforcement programs. Journal of Zoology, 299, 132-141.

Reed, J.Z., Tollit, D.J., Thompson, P. \& Amos, W. (1997) Molecular scatology: the use of molecular genetic analysis to assign species, sex and individual identity to seal faeces. Molecular Ecology, 6, 225-234.

Ritchie, E.G. \& Johnson, C.N. (2009) Predator interactions, mesopredator release and biodiversity conservation. Ecology Letters, 12, 982-998.

Rosenstock, S.S. (1998) Influence of gambel oak on breeding birds in ponderosa pine forests of northern Arizona. The Condor, 100, 485492.

SAGAR, R. \& SINGH, J.S. (2004) Local plant species depletion in a tropical dry deciduous forest of northern India. Environmental Conservation, 31, 55-62.

Sankar, K. \& Johnsingh, A.J.T. (2002) Food habits of tiger (Panthera tigris) and leopard (Panthera pardus) in Sariska Tiger Reserve, Rajasthan, India, as shown by scat analysis. Mammalia, 66, 285-289.
SARKAR, A. \& DAS, A.P. (2012) Contribution of forest flora in rural livelihood: a study of Jayanti, Buxa Tiger Reserve, West Bengal, India. Pleione, 6, 132-140.

SATHYAKUmar, S. (2001) Status and management of Asiatic black bear and Himalayan brown bear in India. Ursus, 12, 21-29.

Sathyakumar, S., Bashir, T., Bhattacharya, T. \& Poudyal, K. (2011) Assessing mammal distribution and abundance in intricate eastern Himalayan habitats of Khangchendzonga, Sikkim, India. Mammalia, 75, 257-268.

Schoener, T.W. (1993) On the relative importance of direct vs indirect effects in ecological communities. In Mutualism and Community Organization: Behavioral, Theoretical, and Food-Web Approaches (eds H. Kawanabe, J.E. Cohen \& K. Iwasaki), pp. 365-411. Oxford University Press, Oxford, UK.

Shehzad, W., Riaz, T., Nawaz, M.A., Miquel, C., Poillot, C., $\mathrm{S}_{\mathrm{HAH}}$, S.A. et al. (2012) Carnivore diet analysis based on nextgeneration sequencing: application to the leopard cat (Prionailurus bengalensis) in Pakistan. Molecular Ecology, 21, 1951-1965.

Sih, A., Crowley, P., McPeek, M., Petranka, J. \& Strohmeier, K. (1985) Predation, competition and prey communities: a review of field experiments. Annual Review of Ecology and Systematics, 16, 269-311.

Sih, A., Englund, G. \& Wooster, D. (1998) Emergent impacts of multiple predators on prey. Trends in Ecology \& Evolution, 13, 350-355.

Singh, M. \& SinHA, A. (2004) Life history traits: ecological adaptations or phylogenetic relics? In Macaque Societies: A Model for the Study of Social Organization (eds B. Thierry, M. Singh \& W. Kaumanns), pp. 80-83. Cambridge University Press, Cambridge, UK.

SinHA, R.K. \& DAS, B.K. (2003) The Buxa case study. Unpublished paper presented at the IVth World Parks Congress, Durban, South Africa.

Smith, A.T., Xie, Y., Hoffmann, R.S., Lunde, D., MacKinnon, J., Wilson, D.E. \& Wozencraft, W.C. (2010) A Guide to the Mammals of China. Princeton University Press, Princeton, USA.

Smith, J.L.D., McDougal, C., Ahearn, S.C., Joshi, A. \& Conforti, K. (1999) Metapopulation structure of tigers in Nepal. In Riding the Tiger: Tiger Conservation in Human-Dominated Landscapes (eds J. Seidensticker, S. Christie \& P. Jackson), pp. 176-189. Cambridge University Press, Cambridge, UK.

Stein, A.B., Athreya, V., Gerngross, P., Balme, G., Henschel, P., Karanth, U. et al. (2016) Panthera pardus. In The IUCN Red List of Threatened Species 2016: e.T15954A102421779. Http://www. iucnredlist.org/details/15954/o [accessed 3 February 2017].

WANG, S.W. \& MACDONALD, D.W. (2009) The use of camera traps for estimating tiger and leopard populations in the high altitude mountains of Bhutan. Biological Conservation, 142, 606-613.

Wilson, D.E. \& Burnie, D. (2001) Animal: The Definitive Visual Guide to the World's Wildlife. Dorling Kindersley, London, UK.

\section{Biographical sketches}

Mriganka Shekhar Sarkar studies the ecology and conservation biology of large mammals. HARIKA SEGU works on population genetics and DNA forensics of tigers. J.V. BHASKAR and RAJENDRA JAKHER are officers in the West Bengal Forest Department. SWATI Mohapatra and K. Shalini contributed to this study as part of their MSc research. S. SHIVAJI has conducted research in conservation biology and animal reproduction, and is currently focused on microbial biodiversity. P. ANURADHA REDDY studies the conservation biology and population genetics of threatened mammals in India. 